\title{
Pengolahan Bubuk Kopi sebagai Variasi Produk Olahan Hasil Bumi Masyarakat di Pekon Karang Rejo Kecamatan Ulubelu Kabupaten Tanggamus Provinsi Lampung
}

\section{Coffee Powder Processing as a Variation of Processed Products of Community-Owned Products in Karang Rejo Village, Ulubelu Subdistrict, Tanggamus Regency, Lampung Province}

${ }^{1}$ Ardian Asyhari, ${ }^{2}$ Winda Septiana, ${ }^{2}$ Era Gunti, ${ }^{2 E v a n ~ S u p r i y a d i, ~}{ }^{2}$ Fitria Amalia, ${ }^{2}$ Imam Nur Cahyo, ${ }^{2}$ Intan Riyanti, ${ }^{2}$ Kurnia Dona Audri, ${ }^{2}$ Mar'atun Mukarromah, ${ }^{2}$ Mutiara Ayunda, ${ }^{2}$ Rani Antari Tendani, 2Ubay Khafindar, 2Yudi Chrisna, ${ }^{2}$ Yuliana

1Jurusan Pendidikan Fisika, Fakultas Tarbiyah dan Keguruan, Universitas Islam Negeri Raden Intan Lampung, Lampung

${ }^{2}$ Mahasiswa KKN Kelompok 181, Universitas Islam Negeri Raden Intan Lampung, Lampung

Korespondensi: A. Asyhari, ardianasyhari@radenintan.ac.id

Naskah Diterima: 20 September 2019. Disetujui: 10 Februari 2020. Disetujui Publikasi: 11 Juni 2020

\begin{abstract}
Karang Rejo is a village in Ulubelu Subdistrict, Tanggamus Regency, Lampung Province. In this community service activity, we introduce the processing of coffee powder as a variety of processed agricultural products from the community, starting from what materials are used, how to manufacture to produce agricultural products that can be of economic value considering that the people in Karang Rejo Village only use coffee grounds to be used as drinks. Therefore, the purpose of this community service is to share knowledge on how to process coffee into processed coffee crackers by observing and counseling the processing of coffee crackers. Evaluation of the increase in participant knowledge was carried out by pre-test before counseling on how to process and post-test after counseling. Processing practices are carried out when counseling is carried out. The results of the activity showed that the enthusiasm of the citizens, especially the PKK mothers, and showed an increase in basic knowledge about the processing of coffee crackers, the benefits, and ways of making coffee-based crackers. The service of processing coffee grounds into coffee crackers is considered auspicious and beneficial for improving the economy in Karang Rejo Village.

Keywords: Coffee powder, coffee crackers, community development, karang rejo village.

Abstrak. Karang Rejo adalah salah satu Pekon yang berada di Kecamatan Ulubelu Kabupaten Tanggamus Provinsi Lampung. Kegiatan pengabdian pada masyarakat ini mengenalkan pengolahan bubuk kopi sebagai variasi produk olahan hasil bumi masyarakat mulai bahan apa saja yang digunakan, cara pembuatan hingga menjadikan hasil bumi yang dapat bernilai ekonomis. Mengingat bahwa masyarakat di Pekon Karang Rejo ini hanya memanfaatkan bubuk kopi untuk dijadikan minuman. Tujuan pengabdian kepada masyarakat ini adalah untuk berbagi ilmu mengenai cara pengolahan kopi menjadi olahan kerupuk kopi dengan cara observasi serta penyuluhan pengolahan kerupuk kopi tersebut. Evaluasi peningkatan pengetahuan peserta dilakukan dengan pre-test sebelum dilakukan penyuluhan cara pengolahan dan
\end{abstract}


post-test setelah dilakukan penyuluhan. Praktik pengolahan dilakukan pada saat penyuluhan dilaksanakan. Hasil kegiatan menunjukkan bahwa adanya antusias warga khususnya para ibu PKK dan adanya peningkatan pengetahuan dasar mengenai olahan kerupuk kopi, manfaat, dan cara pembuatan kerupuk berbahan dasar kopi. Kegiatan pengabdian pengolahan bubuk kopi menjadi kerupuk kopi tergolong berhasil dan bermanfaat untuk peningkatan perekonomian di Pekon Karang Rejo.

Kata Kunci: Bubuk kopi, kerupuk kopi, pengabdian, pekon karang rejo.

\section{Pendahuluan}

Lampung merupakan Provinsi yang berada di Pulau Sumatera. Lampung terkenal akan komoditas kopinya dan masuk dalam salah satu Provinsi penghasil kopi robusta terbesar di Indonesia. Perkebunan kopi sebagian besar berpusat di Kabupaten Lampung Barat, Tanggamus dan Way Kanan (BPS Kabupaten Tanggamus, 2014). Salah satu sentra komoditi kopi di Lampung yakni Kabupaten Tanggamus, hal ini dapat dilihat dari luasnya yang mencapai 44.330 ha dan hasil produksi yaitu sebanyak 36.520 ton (Lestari, dkk., 2017). Kecamatan Ulubelu merupakan salah satu sentra produksi kopi di Kabupaten Tanggamus khususnya di Pekon Karang Rejo. Pekon Karang Rejo berada didaerah wilayah Kecamatan Ulubelu Kabupaten Tanggamus Provinsi Lampung. Letak Pekon Karang Rejo berada di sebelah Barat Pekon Pagar Alam dan Sebelah Timur berbatasan dengan Pekon Gunung Tiga dan terbagi dalam enam wilayah pedusunan yang dipimpin oleh seorang Kepala Dusun dan Kepala RT. Pekon Karang Rejo mulai berdiri pada zaman kolonialisasi sekitar tahun 40-an. Pencetus berdirinya Pekon Karang Rejo berasal dari masyarakat jawa yang melakukan program transmigrasi dan juga karena kondisi kolonisasi yang terjadi di Indonesia. Pekon Karang Rejo memiliki luas wilayah 5.917 ha dengan lahan produktif 4.890 ha. Total luas tata guna tanah Pekon Karang Rejo adalah 1599 ha; terdiri atas pemukiman 100 ha; sawah 90 ha; perkebunan 1.400 ha; pemakaman dan jalan 7 ha; perkantoran 2 ha, dan sisanya untuk penggunaan lainnya (RPJM Pekon Karang Rejo Kecamatan Ulubelu, 2016). Mata pencaharian sebagian penduduk adalah petani, sedangkan hasil produksi ekonomis Pekon yang menonjol adalah perkebunan kopi. Namun demikian, masyarakat belum mengembangkan komoditi-komoditi tersebut sebagai suatu unit usaha komersial yang memberikan pendapatan yang tinggi bagi masyarakat secara berkelanjutan (Makkarennu, dkk., 2018).

Berdasarkan (Peraturan Menteri Pertanian, 2014) kopi merupakan komoditas perkebunan yang memegang peranan penting dalam perekonomian Indonesia. Kopi pada dasarnya adalah tumbuhan yang sangat mudah ditemukan di berbagai daerah di Indonesia. Tumbuhan ini pada umumnya ditanam di pegunungan yang memiliki suhu udara dingin. Kopi di Indonesia diperdagangkan dalam bentuk kopi biji, kopi sangrai, kopi bubuk, kopi instan, dan bahan makanan lain yang mengandung kopi (Rismunandar \& Paimin, 2001). Kopi Indonesia sebagian besar dihasilkan oleh Sumatera Selatan, Bengkulu dan Lampung (Yuhono, 2012).

Program Pengabdian Masyarakat ini fokus pada pengolahan bubuk kopi dalam rangka untuk meningkatkan keterampilan ibu-ibu PKK Pekon Karang Rejo khususnya di Blok 05 dan 06. Pemanfaatan bubuk kopi khususnya pada masyarakat Pekon Karang Rejo selama ini hanya diolah sebagai minuman yang dikonsumsi sehari-hari dan selain itu sebagian hasil panen biji kopi dijual ke penampung kopi namun harga jualnya masih cukup rendah. Dari hasil wawancara yang kami lakukan pada sebagian warga, harga jual untuk kopi yang masih berbentuk biji kopi ialah Rp.18.000/kg atau kurang dari Rp. 20.000/kg. Oleh karena itu, tujuan program pengabdian ini ialah memberikan informasi kepada masyarakat setempat melalui observasi dan penyuluhan dalam mengolah bubuk kopi menjadi kerupuk kopi hingga menjadi produk olahan yang bernilai ekonomis tinggi. Selain itu juga untuk meningkatkan akses pasar produk olahan bubuk kopi 
di masyarakat melalui produk kerupuk kopi. Manfaat dari program pengabdian masyarakat ini ialah masyarakat dapat memanfaatkan tanaman kopi khususnya bubuk kopi menjadi produk olahan yang dapat bernilai ekonomis tinggi seperti dijadikan kerupuk kopi sehingga dapat meningkatkan kesejahteraan masyarakat serta ibu-ibu PKK Pekon Karang Rejo.

\section{Metode Pelaksanaan}

Tempat dan Waktu. Kegiatan program pengabdian masyarakat ini dilaksanakan di Pekon Karang Rejo Kecamatan Ulubelu Kabupaten Tanggamus Provinsi Lampung. Waktu yang ditempuh dari Bandar Lampung ke Pekon karang Rejo \pm 4 jam perjalanan. Waktu pelaksanaan program ini yaitu dari bulan Juli 2019Agustus 2019.

Khalayak Sasaran. Sasaran program kegiatan ini ialah ibu-ibu PKK serta semua masyarakat khususnya masyarakat yang berada di blok 05 dan 06 Pekon Karang Rejo. Jumlah peserta kegiatan sosialisasi tersebut adalah 38 orang (sudah termasuk ibu-ibu PKK dan anak-anak serta sebagian aparat Pekon Karang Rejo).

Metode Pengabdian. Metode pelaksanaan dalam program kegiatan ini bertujuan untuk mendapatkan solusi dari permasalahan yang telah diuraikan sebelumnya sehingga dapat mendukung terlaksananya kegiatan (Noor, dkk., 2018). Metode yang digunakan dalam program pengabdian masyarakat ini adalah observasi dan penyuluhan tentang cara pengolahan bubuk kopi menjadi kerupuk kopi. Penyuluhan dilakukan pada malam hari setelah bakda magrib dilaksanakan bersamaan dengan acara perpisahan kegiatan pengabdian masyarakat. Adapun dalam penyuluhan berlangsung kami menyampaikan beberapa topik penjelasan, yakni: tentang apa saja olahan hasil bumi yang dapat di olah menjadi olahan yang dapat bernilai ekonomis di Pekon Karang Rejo yaitu diantaranya ada kopi yang dapat dibuat olahan camilan seperti kerupuk kopi, pepaya yang dapat diolah menjadi keripik kates dan kulit singkong yang dapat diolah menjadi keripik kulit singkong. Selain itu kami juga menjelaskan dari mulai bahan apa saja yang dibutuhkan untuk membuat olahan kerupuk kopi, serta bagaimana cara pembuatan kerupuk kopi sampai dengan pengemasan produk olahan kerupuk kopi ini.

Indikator Keberhasilan. Program kegiatan pengabdian masyarakat ini dapat dikatakan berhasil atau tercapai sesuai target jika lebih dari $80 \%$ ibu-ibu PKK serta masyarakat setempat memiliki wawasan dan mampu mengolah bubuk kopi menjadi suatu variasi produk olahan hasil bumi masyarakat yang bernilai ekonomis tinggi melalui produk kerupuk kopi ini.

Metode Evaluasi. Metode evaluasi pelaksanaan yang dilaksanakan yakni menggunakan metode pre test serta post-test. Pre-test dilakukan sebelum dan posttest dilakukan setelah kegiatan penyuluhan (Rifa'i, dkk., 2017, 2018; Kudsiah, dkk., 2018; Dewi \& Widiyawati, 2019) dengan mengisi kuesioner (Gambar 1). Kemudian dievaluasi dengan menyesuaikan dari indikator keberhasilan program kegiatan ini.

\section{Hasil dan Pembahasan}

\section{A. Observasi}

Tahap observasi dimulai dengan pendekatan kepada masyarakat dengan cara membuat kuesioner mengenai pekerjaan serta tanaman apa yang dominan mereka tanam di kebun. Selanjutnya menyampaikan kepada masyarakat berkaitan dengan program kegiatan pengabdian masyarakat yang akan dilakukan yakni sosialisasi tentang olahan bubuk kopi yang dapat diolah menjadi kerupuk kopi sehingga dapat bernilai ekonomis tinggi.

\section{B. Persiapan}

Persiapan dilakukan dengan beberapa tahap, yakni dengan menyiapkan bahan-bahan yang akan digunakan pada saat pengolahan bubuk kopi menjadi 
kerupuk kopi. Kemudian memulai pengolahan kerupuk kopi, untuk mengolah bubuk kopi sampai menjadi kerupuk kopi kami membutuh kan waktu sekitar 3-4 hari dengan jumlah $1 \mathrm{~kg}$ olahan kerupuk kopi (kerupuk kopi akan kering apabila cahaya matahari terik) dan proses penjemuran kerupuk dapat memakan waktu lama apabila cahaya matahari tidak terik. Lama proses pengeringan tergantung bahan yang dikeringkan dan cara pemanasan yang digunakan (Sativa, dkk., 2014).

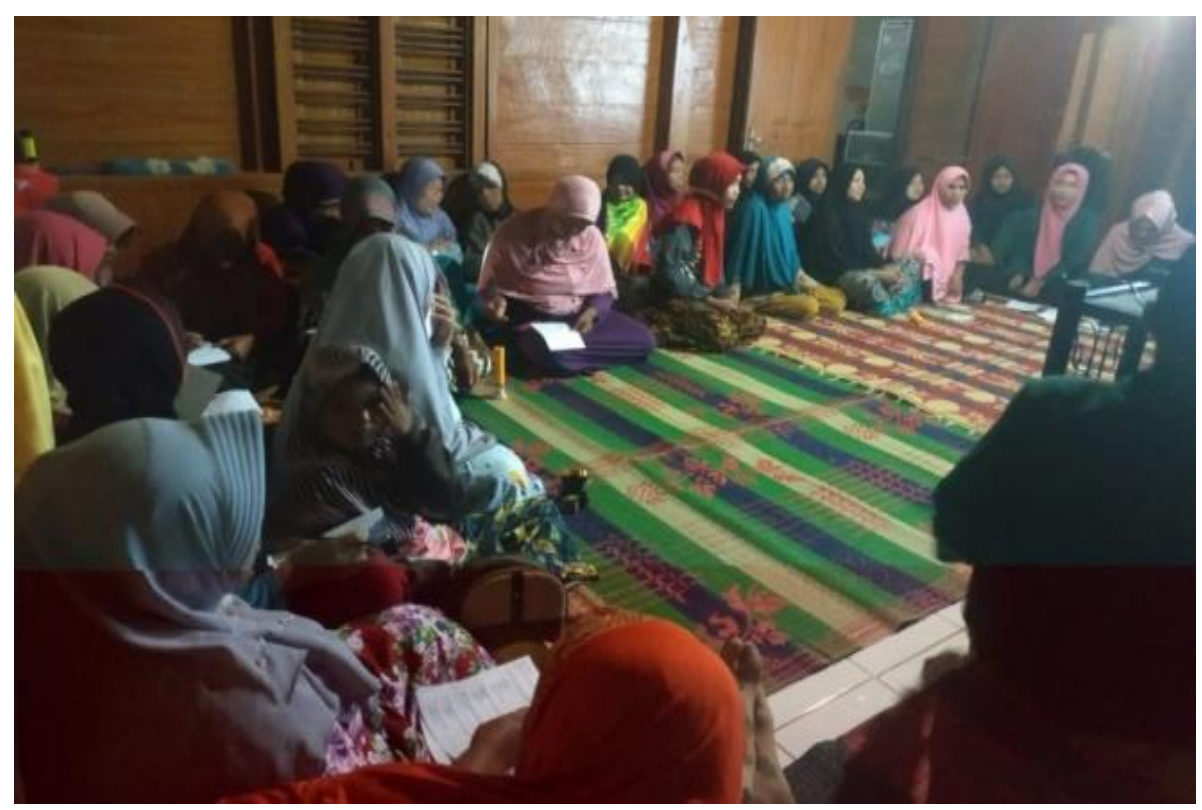

Gambar 1. Dokumentasi pengisian kuisioner

\section{Penyuluhan}

Pengolahan bubuk kopi yang dilakukan pada kegiatan ini dimulai dari Penyuluhan. Penyuluhan yang dilakukan kepada masyarakat Pekon Karang Rejo yakni tentang pengolahan bubuk kopi sebagai variasi produk olahan hasil bumi masyarakat yang akan dijadikan produk kerupuk kopi. Penyuluhan kami laksanakan bersamaan dengan acara perpisahan kegiatan pengabdian masyarakat. Dalam Penyuluhan ini berlangsung diharapkan mampu memberikan pengetahuan mengenai olahan bubuk kopi yang dapat di kembangkan menjadi olahan yang baru dan mampu dikembangkan oleh masyarakat setempat menjadi olahan yang bernilai ekonomis tinggi guna meningkatkan perekonomian Pekon Karang Rejo. Penyuluhan juga dilakukan untuk memberikan informasi kepada masyarakat mengenai jenis-jenis kopi serta manfaat dari biji kopi. Kegiatan penyuluhan ini kami sampaikan melalui paparan oral dan visual menggunakan power point, serta ditambahkan dengan penayangan video pendek tentang cara pengolahan bubuk kopi menjadi kerupuk kopi yang gunanya untuk memudahkan agar masyarakat lebih memahami cara pengolahan produk tersebut.

Saat penyuluhan berlangsung dikembangkan pula kesempatan diskusi, yang bertujuan untuk menambah informasi dan pengetahuan para ibu PKK serta masyarakat setempat tentang tata cara pengolahan yang akan diterapkan serta peluang dan juga hambatan yang mungkin dapat terjadi saat melakukan kegiatan pengolah kerupuk kopi. Penyuluhan yang berlangsung dikatakan cukup menarik dilihat dari antusiasme yang tinggi masyarakat dalam mengajukan beberapa pertanyaan terkait dengan apa saja manfaat dari kopi sehingga dapat dibuat olahan kerupuk kopi, dan persentase modal yang digunakan dalam pembuatan kerupuk kopi, serta mengenai pemasaran produk kerupuk kopi.

Program kegiatan pengabdian masyarakat yang dilakukan di Pekon Karang Rejo blok 05 dan 06 terkait penyuluhan ditampilkan pada Gambar 2 - 4. 

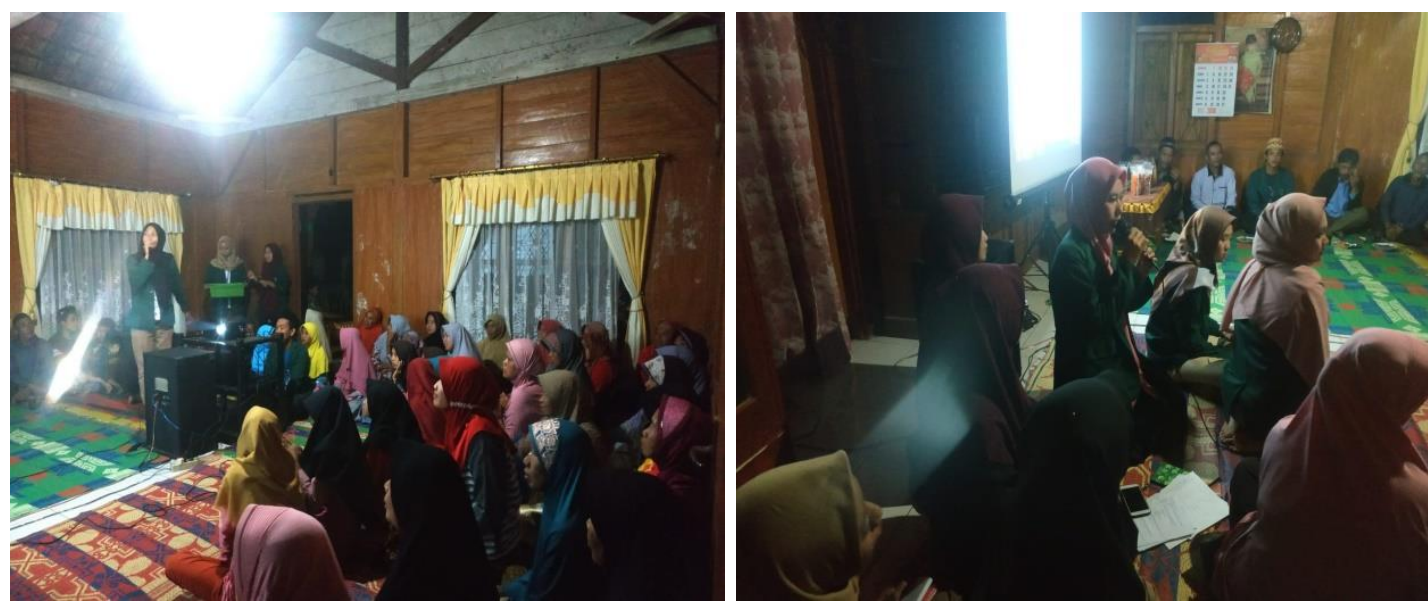

Gambar 2. Pemaparan materi
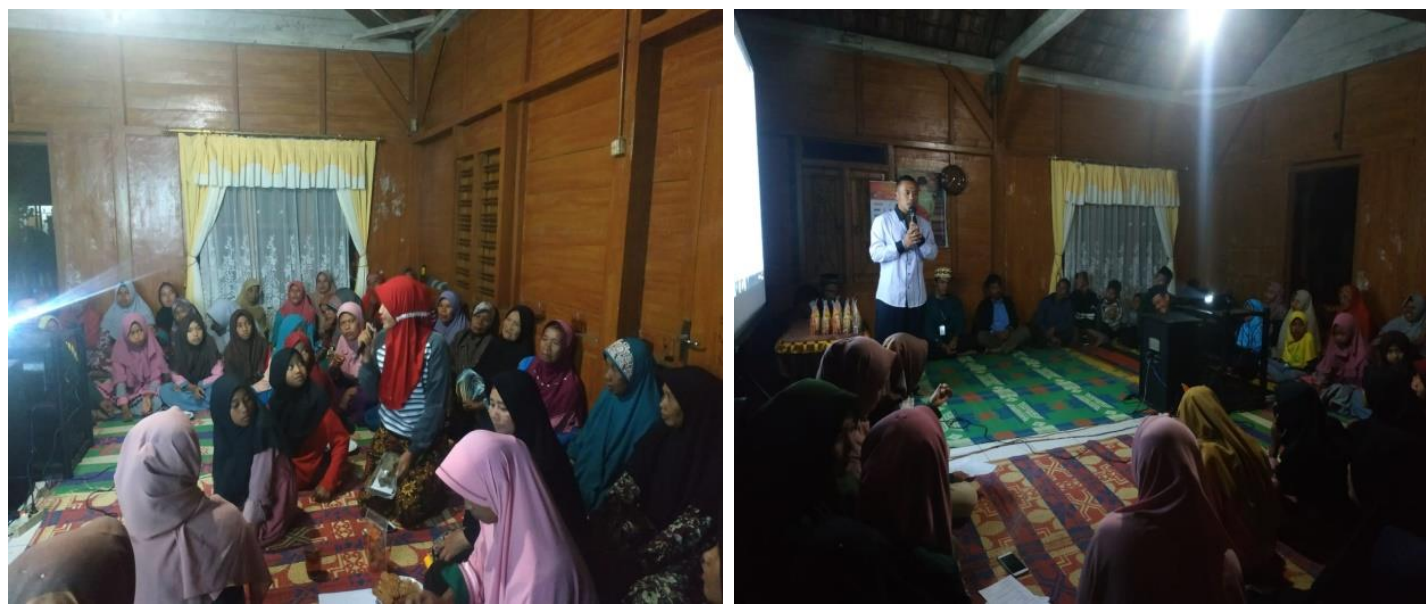

Gambar 3. Antusiasme Masyarakat mengajukan pertanyaan
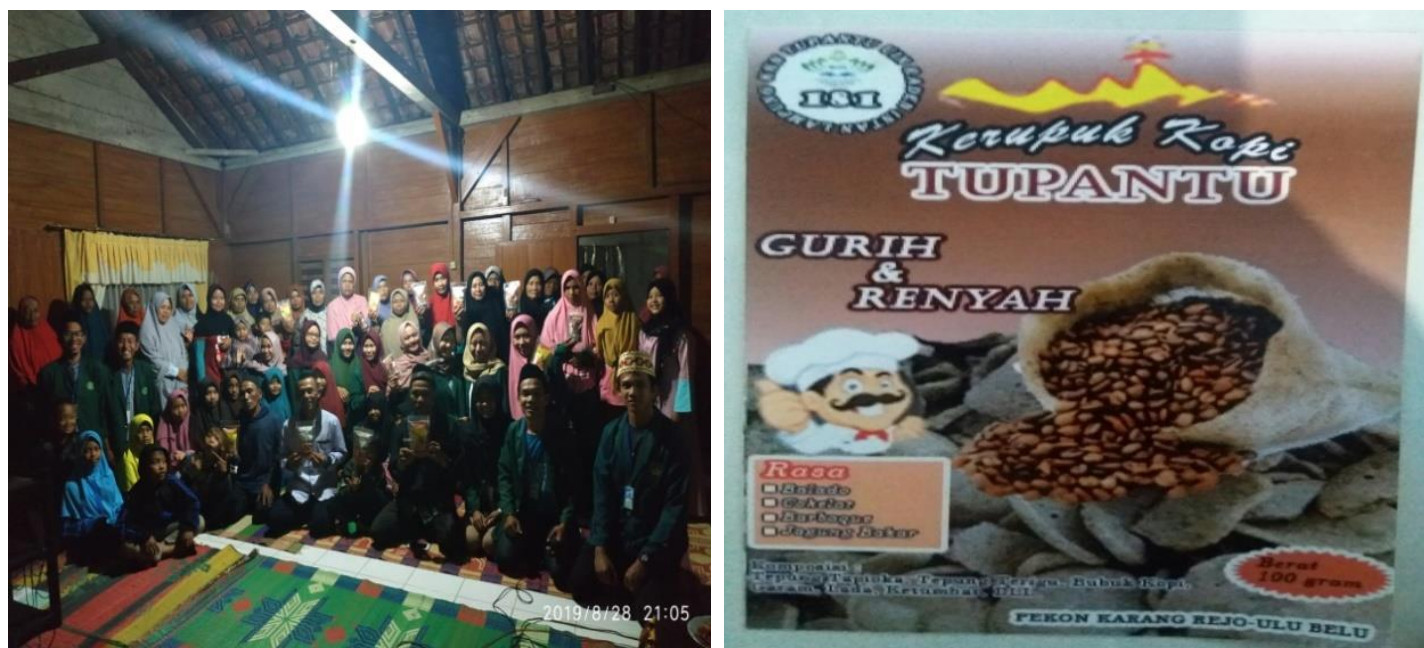

Gambar 4. Foto bersama masyarakat Pekon Karang Rejo dan produk kerupuk kopi

\section{Keberhasilan Kegiatan}

Dalam kegiatan penyuluhan yang dilakukan, adapun masyarakat yang menjadi peserta dalam penyuluhan tersebut berjumlah 38 orang. Berdasarkan kegiatan yang dilakukan dari tahapan observasi hingga penyuluhan target keberhasilan yang telah dicapai pada kegiatan ini dapat dilihat pada tabel 1 dan 2: 
Tabel 1. Pre-test Kuesioner

\begin{tabular}{|c|c|c|c|c|c|}
\hline \multirow{2}{*}{ No. } & \multirow{2}{*}{ Pertanyaan } & \multicolumn{2}{|c|}{ Menjawab Ya } & \multicolumn{2}{|c|}{ Menjawab Tidak } \\
\hline & & Jumlah & Persentase & Jumlah & Persentase \\
\hline 1 . & $\begin{array}{l}\text { Apakah Anda mengetahui } \\
\text { produk olahan kopi selain } \\
\text { menjadi bubuk kopi ? }\end{array}$ & 6 & $15 \%$ & 32 & $85 \%$ \\
\hline 2. & $\begin{array}{l}\text { Apa Anda mempunyai } \\
\text { penghasilan selain dari } \\
\text { kopi? }\end{array}$ & 24 & $63 \%$ & 14 & $37 \%$ \\
\hline 3. & $\begin{array}{l}\text { Tertarikkah Anda mengolah } \\
\text { kopi menjadi olahan lain ? }\end{array}$ & 35 & $92 \%$ & 3 & $7 \%$ \\
\hline 4. & $\begin{array}{l}\text { Apakah Anda mengetahui } \\
\text { tentang kerupuk kopi ? }\end{array}$ & 4 & $10 \%$ & 34 & $90 \%$ \\
\hline 5. & $\begin{array}{l}\text { Apakah Anda mengetahui } \\
\text { cara pembuatan kerupuk } \\
\text { kopi ? }\end{array}$ & 0 & $0 \%$ & 38 & $100 \%$ \\
\hline
\end{tabular}

Tabel 2. Post-test (Kuesioner)

\begin{tabular}{|c|c|c|c|c|c|}
\hline \multirow{2}{*}{ No. } & \multirow{2}{*}{ Pertanyaan } & \multicolumn{2}{|c|}{ Menjawab Ya } & \multicolumn{2}{|c|}{ Menjawab Tidak } \\
\hline & & Jumlah & Persentase & Jumlah & Persentase \\
\hline 1. & $\begin{array}{l}\text { Apakah Anda mengetahui } \\
\text { produk olahan kopi selain } \\
\text { menjadi bubuk kopi ? }\end{array}$ & 38 & $100 \%$ & 0 & $0 \%$ \\
\hline 2. & $\begin{array}{l}\text { Apa Anda mempunyai } \\
\text { penghasilan selain dari } \\
\text { kopi? }\end{array}$ & 24 & $63 \%$ & 14 & $37 \%$ \\
\hline 3. & $\begin{array}{l}\text { Tertarikkah Anda mengolah } \\
\text { kopi menjadi olahan lain? }\end{array}$ & 38 & $100 \%$ & 0 & $0 \%$ \\
\hline 4. & $\begin{array}{l}\text { Apakah Anda mengetahui } \\
\text { tentang kerupuk kopi? }\end{array}$ & 38 & $100 \%$ & 0 & $0 \%$ \\
\hline 5. & $\begin{array}{l}\text { Apakah Anda mengetahui } \\
\text { cara pembuatan kerupuk } \\
\text { kopi ? }\end{array}$ & 38 & $100 \%$ & 0 & $0 \%$ \\
\hline
\end{tabular}

Tingkat keberhasilan kegiatan dapat dilihat apabila kegiatan tersebut telah terealisasikan. Dari data Pre-test dan Post Test menunjukkan bahwa masyarakat setempat yang mayoritas bekerja sebagai petani kopi mulanya tidak mengetahui bahwa kopi dapat dijadikan olahan lain selain bubuk kopi yakni seperti halnya kerupuk kopi, masyarakat hanya mengolah kopi untuk dijadikan bubuk kopi saja yang dinikmati sehari-hari serta hasil panen dominannya dijual ke penampung kopi dengan harga jual yang rendah. Oleh karena itu kegiatan ini masih relevan dengan kebutuhan masyarakat di Pekon Karang Rejo terutama untuk meningkatkan olahan hasil bumi yang dapat bernilai ekonomis.

Setelah penyuluhan dilakukan sebagai upaya program kegiatan pengabdian masyarakat, masyarakat sangat antusias dan tertarik untuk mencoba mengolah bubuk kopi menjadi kerupuk kopi sehingga dapat dijual dan dapat meningkatkan penghasilan mereka.

\section{Kesimpulan}

Program kegiatan pengabdian masyarakat ini tergolong berhasil, karena lebih dari $80 \%$ ibu-ibu PKK serta masyarakat setempat memiliki wawasan dan mampu mengolah bubuk kopi menjadi suatu variasi produk olahan hasil bumi masyarakat 
yang bernilai ekonomis tinggi melalui produk kerupuk kopi. Selain itu, masyarakat Pekon Karang Rejo juga sangat antusias dalam mengikuti kegiatan pengolahan bubuk kopi menjadi kerupuk kopi.

\section{Ucapan Terima Kasih}

Penulis menyampaikan terima kasih kepada Kepala Pekon, Aparat Pekon, serta para petani kopi di Pekon Karang Rejo atas bantuannya selama menjalani program kegiatan pengabdian masyarakat ini.

\section{Referensi}

BPS Kabupaten Tanggamus. (2014). Tanggamus Dalam Angka 2014. Kota Agung: BPS Kabupaten Tanggamus.

Dewi. P.S., \& Widiyawati, I. (2019). Pengenalan Teknologi Budidaya Tanaman Obat sebagai Upaya Pemanfaatan Lahan Pekarangan di Kelurahan Pabuwaran, Jawa Tengah. Jurnal Panrita Abdi, (3)2, 105 - 112.

Kudsiah, H., Tresnati, J., Ali , S.A., \& Rifa'i, M.A. (2018). IbM Kelompok Usaha Bandeng Segar Tanpa Duri di Kabupaten Pangkep Sulawesi Selatan. Panrita Abdi Jurnal, 2(1), 55-63.

Lestari, O., Hasyim, A.I., \& Kasymir, E. (2017). Analisis Usahatani dan Efisiensi Pemasaran Kopi (Coffea sp) di Kecamatan Pulau Panggung Kabupaten Tanggamus. Jurnal JIIA, Volume 5 (1), 1 - 8.

Makkarennu, Syahidah, Ridwan, Sahide, M.A.K., \& Mas'ud, E.I.R. (2018). Pengembangan Pasar dan Penguatan Kapasitas Kewirausahaan Kelompok Tani Hutan di Sekitar Kawasan Hutan Pendidikan Unhas. Jurnal Panrita Abdi Jurnal, 2(1), 64 -74.

Noor, S.Y., Adipu, Y., \& Auliyah, N. (2018). Pendampingan Budidaya Kerapu Tikus Pada Kelompok Bahtera Lamu dan Bahari di Desa Lamu Kabupaten Bualemo. Jurnal Panrita Abdi, 2(1), 32 - 39.

Peraturan Menteri Pertanian (2014). Pedoman Teknis Budidaya Kopi yang Baik (Good Agriculture Practices/Gap On Coffe). Jakarta: Kementerian Pertanian Direktoat Jenderal Perkebunan.

Rifa'i, M.A., Kudsiah, H., \& Muzdalifah. (2017). Alih teknologi produksi benih anemon laut secara aseksual. Jurnal Panrita Abdi, 1(1), 33-39.

Rifa'i, M.A., Syahdan, M., Muzdalifah, \& Kudsiah, H. (2018). Pengembangan Usaha Produk Intelektual Kampus: Anemon Laut Ornamen. Jurnal Panrita Abdi, 2(1), 40-47.

Rismunandar \& Paimin, F.B. (2001). Kayu Manis Budidaya dan Pengolahan. Surabaya: Penebar Swadaya.

RPJM Pekon Karang Rejo Kecamatan Ulubelu. (2016). Lampiran Peraturan Pekon Karang Rejo Nomor 02 Tahun 2016 Tentang Rencana Pembangunan Jangka Menengah Pekon (RPJM Pekon). Pekon Karang Rejo: RPJM Pekon Karang Rejo Kecamatan Ulubelu.(Tidak dipublikasikan).

Sativa, O., Yuwana, \& Bonodikun. (2014). Karakteristik Fisik Buah Kopi, Kopi Beras dan Hasil Olahan Kopi Rakyat di Desa Sindang Jati, Kabupaten Rejang Lebong, Jurnal Agro Industri, 4(2), 65 - 77.

Yuhono (2012). Penerapan Sistem Nilai Cacat (defect System) Dan Citarasa Kopi di Provinsi Lampung. Bandar Lampung: Pusat Penelitian Sosial Ekonomi Kehutanan. (Tidak dipublikasikan).

Penulis:

Ardian Asyhari, Jurusan Pendidikan Fisika, Fakultas Tarbiyah dan Keguruan, Universitas Islam Negeri Raden Intan Lampung, Lampung. E-mail: ardianasyhari@radenintan.ac.id

Winda Septiana, Mahasiswa KKN Kelompok 181, Universitas Islam Negeri Raden Intan Lampung, Lampung. E-mail: windaseptiana@gmail.com 
Era Gunti, Mahasiswa KKN Kelompok 181, Universitas Islam Negeri Raden Intan Lampung, Lampung. E-mail: eragunti@gmail.com

Evan Supriyadi, Mahasiswa KKN Kelompok 181, Universitas Islam Negeri Raden Intan Lampung, Lampung. E-mail: evansupriyadi@gmail.com

Fitria Amalia, Mahasiswa KKN Kelompok 181, Universitas Islam Negeri Raden Intan Lampung, Lampung. E-mail: fitriaamalia@gmail.com

Imam Nur Cahyo, Mahasiswa KKN Kelompok 181, Universitas Islam Negeri Raden Intan Lampung, Lampung. E-mail: imamnurcahyo@gmail.com

Intan Riyanti, Mahasiswa KKN Kelompok 181, Universitas Islam Negeri Raden Intan Lampung, Lampung. E-mail: intanriyanti@gmail.com

Kurnia Dona Audri, Mahasiswa KKN Kelompok 181, Universitas Islam Negeri Raden Intan Lampung, Lampung. E-mail: kurniadonaaudri@gmail.com

Mar'atun Mukarromah, Mahasiswa KKN Kelompok 181, Universitas Islam Negeri Raden Intan Lampung, Lampung. E-mail: maratunmukarromah@gmail.com

Mutiara Ayunda, Mahasiswa KKN Kelompok 181, Universitas Islam Negeri Raden Intan Lampung, Lampung. E-mail: mutiaraayunda@gmail.com

Rani Antari Tendani, Mahasiswa KKN Kelompok 181, Universitas Islam Negeri Raden Intan

Lampung, Lampung. E-mail: raniantari@gmail.com

Ubay Khafindar, Mahasiswa KKN Kelompok 181, Universitas Islam Negeri Raden Intan Lampung, Lampung. E-mail: ubaykhafindar@gmail.com

Yudi Chrisna, Mahasiswa KKN Kelompok 181, Universitas Islam Negeri Raden Intan Lampung, Lampung. E-mail: yudichrisna@gmail.com

Yuliana, Mahasiswa KKN Kelompok 181, Universitas Islam Negeri Raden Intan Lampung, Lampung. E-mail: yulianachan@gmail.com

Bagaimana mensitasi artikel ini:

Asyhari, A. Septiana, W., Gunti, E., Supriyadi, E., Amalia, F., Cahyo, I.N., ... Yuliana, (2020).

Pengolahan Bubuk Kopi sebagai Variasi Produk Olahan Hasil Bumi Masyarakat di Pekon Karang Rejo Kecamatan Ulubelu Kabupaten Tanggamus Provinsi Lampung. Jurnal Panrita Abdi, 4(2), 237 - 244. 